\title{
Evolutionary theory, human uniqueness and the image of God
}

\begin{abstract}
Author:
Gijsbert van den Brink ${ }^{1}$

Affiliation:

${ }^{1}$ Faculty of Theology, VU

University, the Netherlands

Correspondence to:

Gijsbert van den Brink

Email:

gvdbrink@solcon.nl

Postal Address:

Faculty of Theology, VU University Amsterdam, De

Boelelaan 1105, $1081 \mathrm{HV}$

Amsterdam, the Netherlands

Dates:

Received: 23 Mar. 2011

Accepted: 06 June 2011

Published: 19 Oct. 2012

How to cite this article:

Van den Brink, G., 2012,

'Evolutionary theory, human

uniqueness and the image of

God', In die Skriflig/In Luce

Verbi 46(1), Art. \#39, 7 pages.

http://dx.doi.org/10.4102/

ids.v46i1.39
\end{abstract}

C 2012. The Authors.

Licensee: AOSIS

OpenJournals. This work

is licensed under the

Creative Commons

Attribution License.
In this article, I examined what might be called the evolutionary argument against human uniqueness and human dignity. After having rehearsed briefly the roots of the classical JudeoChristian view on human uniqueness and human dignity in the first chapters of Genesis, I went on to explore and delineate the nature of the evolutionary argument against this view. Next, I examined whether Christian theology might widen the concept of imago Dei so as to include other beings as well as humans, thus giving up the idea of human uniqueness. I concluded, however, that this move is deeply problematic. Therefore, I turned to a discussion of some recent attempts to define both human uniqueness and the image of God in theological rather than empirical terms. One of these, which is based on the concept of incarnation, is found wanting, but another one is construed in such a way that it enables us to reconcile the idea of human uniqueness as encapsulated in the doctrine of the imago Dei with contemporary evolutionary theory. Thus, this article can be seen as an exercise in bringing classical Christian theology to terms with evolution, further highlighting this theology's ongoing vitality.

Evolusieteorie, menslike uniekheid and die beeld van God. In hierdie artikel ondersoek ek die sogenaamde evolusionêre argument teen menslike uniekheid en menswaardigheid. $\mathrm{Na}$ 'n kort oorsig oor die oorsprong van die klassieke Joods-Christelike siening van menslike uniekheid en menswaardigheid soos uit die eerste vyf hoofstukke van Genesis blyk, ondersoek en beeld ek die aard van die evolusionêre argument hierteenoor uit. Vervolgens word die vraag ondersoek of die Christelike teologie die konsep van imago Dei sodanig kan verbreed dat dit ook ander wesens behalwe mense kan insluit, waardeur die idee van menslike uniekheid dus prysgegee word. Ek kom egter tot die slotsom dat hierdie skuif hoogs problematies is. Daarom wend ek my tot ' $n$ bespreking van onlangse pogings om menslike uniekheid en die beeld van God eerder in teologiese as empiriese terme te definieer. Een hiervan, gebaseer op die konsep van inkarnasie, is te lig bevind. 'n Ander poging is egter sodanig vertolk dat dit ons in staat stel om die idee van menslike uniekheid, soos ingesluit in die leerstelling van die imago Dei, met die hedendaagse evolusieteorie te versoen. Hierdie artikel kan dus gesien word as 'n poging om die klassieke Christelike teologie in ooreenstemming te bring met evolusie en om hierdie teologie se voortgaande lewenskragtigheid te beklemtoon.

The biblical idea that human beings are created in the image of God and that Homo sapiens are therefore placed more or less at the center of the created universe seems to be especially challenged in our time. (Van Huyssteen 2006:116)

\section{Introduction}

During the past decade, the notions of human rights and human dignity have been at the centre of Koos Vorster's scholarly attention (cf. Vorster 1999, 2000, 2001, 2006, 2008). In Christian theology, these notions have usually been based upon the doctrine of the imago Dei. As Vorster (2008:197), speaking of the Reformed tradition, observes: 'This [human] dignity rests on the human being's imago Dei.' And Kevin Vanhoozer (1997:163) rightly applies this to Christianity in general when he argues that 'Christians ground their affirmation of human dignity ... in the special resemblance of the human creature to its Creator'. Because, according to the Genesis stories, God created all creatures 'after their pattern' but only the human being 'in his image', Jewish and Christian believers have affirmed that there is a unique dividing line between human beings, on the one hand, and all other species, on the other. It is this contrast which somehow undergirds the inviolability of human existence. Whereas God, addressing Noah and his descendants, ordered that 'every moving thing that lives shall be food for you' (Gn 9:3 NRSV), the blood of a human being should not be shed, 'for in his own image God made humankind' (Gn 9:6). Clearly, the suggestion is that whoever assaults a human being thereby touches God, in whose image he or she was made. Thus, from a theological point of view, the notions of human dignity and human rights are heavily dependent on the concept of the imago Dei and the connected belief in human 
uniqueness. It is precisely this latter belief, however, which has come under profound suspicion and criticism as a result of the rise of evolutionary theory during the past century and a half.

In this article, I will explore firstly the nature of this criticism. Next, I examine whether we might widen the concept of imago Dei so as to include other beings as well as humans, thus giving up the idea of human uniqueness. It will turn out, however, that this move is deeply problematic from a Christian theological perspective. Thirdly, some recent attempts to define both human uniqueness and the image of God in theological rather than empirical terms are discussed. One of these is found wanting, but another one is construed in such a way that it enables us to reconcile the idea of human uniqueness as encapsulated in the doctrine of the imago Dei with contemporary evolutionary theory. This article therefore can be seen as an exercise in bringing classical Christian theology to terms with evolution, thus highlighting its ongoing vitality (for a recent attempt to do something similar with regard to another part of Christian theology, viz. its doctrines of sin and evil, see Vorster 2011).

\section{Human nature and the challenge of evolutionary theory}

Evolutionary theory has largely discredited the idea that human beings are radically different from animals - or from 'other animals', as it is often phrased. Given the various kinds of extinct hominid forms of life somewhere in between the extant great apes and Homo sapiens, or even next to the human species from a taxonomical point of view (such as, supposedly, the Neanderthal man) it seems difficult to ascribe any unique-making characteristics to the human being. At the very least, evolutionary theory makes us suspicious of theories that see large gaps between humans on the one hand and the rest of creaturely reality on the other. In particular, the close links between the human being and its closest relative, the chimpanzee, have often been emphasised, especially since the stunning genetic similarity between the two species became clear.

It is often argued that evolutionary theory even leads to the stronger claim that there is no such thing as a 'human nature'. A nature - or in the classical metaphysical jargon: an 'essence' - is an unchanging core of properties that, at the same time, defines a species and distinguishes it from all other species. But does such a notion still make sense in a world in which species evolve in the ways suggested by neo-Darwinian theory? Many argue it does not. For example, philosopher of biology David Hull (1989) writes:

If species evolve in anything like the way that Darwin thought they did, then they cannot possibly have the sort of natures that traditional philosophers claimed they did. If species lack general natures, then so does Homo sapiens as a biological species. If Homo sapiens lacks a nature, then no reference to biology can be made to support one's claims about 'human nature' ... Because so many moral, ethical, and political theories depend on some notion or other of human nature, Darwin's theory brought into question all these theories. (pp. 171-172)
Similarly, theistic philosopher J.P. Moreland (2009), following up on this, argues that:

Darwinism makes it highly unlikely that there is any such thing as a human essence ... that is identical throughout the human species. On a Darwinist view, both species and individual organisms all differ from each other, not in kind, but in degree. (p. 161)

If this is true, however, why would we continue to group organisms in distinctive species? Here is Moreland's answer:

Evolutionary processes are slow and gradual, and where one draws the line that groups members together is somewhat arbitrary. Species turn out to be sets whose members resemble each other to some degree or other. (p. 162)

Whereas for Moreland, this seems to be a reason to reject evolutionary theory, for most others, of course, it is a reason to water down any claims on humanity's special status in creation.

Clearly, however, if we do that it becomes questionable whether we can still adhere to an adequate notion of human dignity. For, as we mentioned, this notion is heavily dependent on the affirmation of human uniqueness: it is because human beings have a special position in creation, being set apart by God from all other living beings, that they deserve the high moral status of having inviolable rights, such as, in any case, the right of life. As James Rachels (1990) argues:

The doctrine of human dignity says that humans merit a level of moral concern wholly different from that to mere animals; for this to be true, there would have to be some big, morally significant difference between them. Therefore, any adequate defence of human dignity would require some conception of human beings as radically different from other animals. But that is precisely what evolutionary theory calls in to question ... This being so, a Darwinian may conclude that a successful defence of human dignity is most unlikely. (pp. 171-172)

So, briefly put, the question is this: how can we uphold a viable account of human dignity in an evolutionary era? Is this even achievable?

\section{Widening the concept of imago Dei?}

One way to proceed here may seem a rather drastic one, but one that, to my mind, should nevertheless be carefully considered. During the past couple of years, some theologians have suggested that the concept of the image of God should be widened so as to include not only humans but also (non-human) animals. This is an intriguing suggestion in the context of our topic, because it might easily be fleshed out in such a way that it reverses Rachels' argument: rather than corroding the conceptual basis for the defence of human dignity by making us humans of no more intrinsic value than the beasts, evolutionary theory actually urges us to ascribe the very same dignity that we traditionally attribute to our own species also to other creatures as well. Perhaps, as Ernst Conradie (2005) puts it:

An affirmation of human dignity ... does not require a strong position on human uniqueness ... The inalienable dignity which we attach to human life may serve as a paradigm for the dignity (or integrity) of the whole earth community. (p. 80) 
In the first place, this may be seen to pertain to the animals. The recent rise of cultural and political movements in the West committed to the defence of 'animal rights' and/or the liberation of animals shows that this suggestion is not as outrageous as it would have been deemed in the past. So let us explore this line of thinking.

The most explicit plea for broadening the concept of imago Dei has recently been made by David Cunningham (2009). Cunningham starts his argument by rightly observing that the sheer existence of empirical distinctions between humans, on the one hand, and animals, on the other, is insufficient to warrant the drawing of any significant theological distinctions between the two. He refers to the fact that most of us now think it were 'poor theological judgments' (2009:102) which prompted theologians over the centuries to conclude, from empirical differences between people of different races or ethnicities, between men and women, or between homosexual and heterosexual people, to the existence of theologically important distinctions between these groups. Similarly, we should be very careful not to value animals differently from a theological perspective for the sole reason that 'they look different, they act differently, and they are treated differently' (2009:102). If a theologically relevant distinction between humans and animals should be maintained, there should be distinctive theological reasons for doing so. Now the most well-known theological reason for such a distinction has been the notion that human beings and human beings alone have been created in the image of God. However, we might wonder to what extent this traditional interpretation of the imago Dei has been influenced by widespread cultural assumptions on the superiority of the human species, based on the Aristotelian view that rationality and the use of language were exclusively human faculties. Since Darwin, we know that this view was wrong and therefore we have some reason to re-examine the imago Dei tradition, probing its biblical and theological warrants.

In doing so, Cunningham (2009) develops a deconstruction of the traditional interpretation of the image of God as limited to human beings in three steps.

Firstly, he points out that, whereas the biblical text explicitly ascribes the image of God only to human beings, it nowhere denies it to other elements of creation. Therefore, we need an argumentum e silentio if we want to make a case for its exclusive ascription to human beings, and arguments from silence are always 'somewhat hazardous, particularly with reference to the Bible' (2009:106).

Secondly, Cunningham (2009:107) observes that even if we grant that the notion of the image of God is only applied to the human being, its precise meaning 'has been one of the more contested sites of theological reflection throughout the centuries'. He then goes on to conclude from this wide range of existing interpretations that 'we are unable to determine its meaning' (2009:110). Thus, the notion is not of much help in gaining a clear theological understanding of what is so special about humanity.
Thirdly, Cunningham (2009) argues that even if we knew its theological meaning, we would still be unable to determine to what extent the concept of imago Dei dissociates human beings from (other) animals and he justifies this claim by pointing to the grammar of the word 'image'. This grammar does not allow for sharp 'either/or' distinctions, because obviously an image can be more or less accurate. It is even impossible to establish at what point an attempted copy is so far away from its original that the language of image ceases to apply (Cunningham mentions the example of a child's poor watercolour drawing of a painting which is only recognisable as a copy by its fondest parent). Moreover, things can be images of a person or object in very different ways. A photograph, for example, images a person in another way than a sculpture does. Finally, to complicate matters further, when it comes to the image of God we have no way to compare any copies to the original, establishing in this way whether some presumed image is sharp, not so sharp, or not an image at all. Cunningham (2009:117) ends his argument by concluding that claims about the creation of human beings in the image of God are 'less supportive of a strong separation between human beings and other animals than might have been surmised'.

To my mind, there is much to be learnt from Cunningham's (2009) explorations. For example, he rightly points to the fact that there are only a few references to the image of God in the Hebrew Bible. In fact, there are only three of them (Gn 1:26-28; 5:1; 9:6), to be sure, there are seven others in the New Testament, but most of these assume Jesus Christ, rather than humanity as a whole, to be the (true) image of God. These data should at least make us pause before we overload the imago Dei concept with theological significance by making it into the cornerstone of theological anthropology. Furthermore, Cunningham also insightfully points out that, at other places, the Bible can just as well divide creaturely reality in different ways than by setting apart humanity from the other creatures. For example, in the story of the flood (Gn 6-8), there is a remnant consisting of both human beings and animals that is saved, whereas all other humans perish with the other animals. Subsequently, when God enters into a new covenant with Noah, this covenant explicitly includes the surviving animals and their offspring (Gn 9:10). Even more telling perhaps is the creation story from Genesis 1, according to which humanity was created on the very same sixth day as the land animals. We were not even allotted a special day for our own species! In this way, the creation story powerfully reminds us of our intimate connectedness with the (other) animals and our profoundly embodied nature; Darwin did not come up with something totally new when he reinforced this point, and Cunningham himself creatively underlines this by conceptualising the central biblical notion of the flesh as an umbrella term that includes both humans and the animals. Finally, Cunningham also convincingly argues that in the biblical texts not only humanity, but the rest of creation as well somehow reflects the 'mark of the Maker'. In the famous opening verse of Psalm 19 it is said that the heavens are telling the glory of God and the firmament proclaims his handiwork. And the more sober prose of Romans 1:20, though its interpretation is notoriously contested, asserts that God's power and divinity transpire in the things God has made. 
Despite all this, and despite the fact that Cunningham (2009) formulates his conclusions in a balanced way, clearly trying to avoid overstating his case, the thrust of his argument remains unconvincing. Let me substantiate this claim by rehearsing briefly his threefold argument. Firstly, Cunningham's suggestion that the biblical text is silent about whether or not the image of God also belongs to non-human animals is slightly misleading, to say the least. Whereas the creation of both plants and animals is said to be 'after their pattern', in the case of the creation of humankind we encounter the words 'in God's image' at the very same place as 'after their pattern'. The linguistic similarity is even stronger, because the phrases are invariably repeated at least twice. Moreover, as we have seen already in Genesis 9, it is said to Noah and his descendants that:

[E]very moving thing that lives shall be food for you, but that the blood of a human being shall not be shed; and this distinction is grounded in the fact that 'in his own image God made humankind. (v. 6)

Clearly, the conclusion cannot be escaped that non-human beings do not share in the image of God, at least not in a way which is poignant enough to give them a moral status of their own.

Secondly, there is indeed a wide variety of interpretations of the notion of the imago Dei both in the Christian tradition and in contemporary theology. The only thing that can be concluded from that, however, is that we should carefully study these interpretations in order to make up our minds as to which are the most plausible ones. Some of them may, as Cunningham (2009) himself notes, be inspired more by reigning cultural assumptions than by the Gospel. Other interpretations are perhaps not as mutually exclusive as one might think at first sight. However this may be, it seems just lazy hermeneutics to conclude from a plurality of interpretations to the impossibility of determining the meaning of a certain phrase or doctrine. In the case of Christian theology, such a conclusion would be particularly disastrous, because there is hardly any doctrinal (or ethical) tenet which has only one clear and generally accepted interpretation - one might hope that there was at least some unanimity on the nature and significance of the Christological and Trinitarian doctrines of the early Church, but even that is of course far from the case. So we would be unable to establish the content of any belief or the meaning of any doctrine if we had to wait until full consensus on their interpretation has been reached. Nor is this typical only for Christian theology - debates on the right interpretation of beliefs and practices are characteristic of all living religious and philosophical traditions (it is perhaps even the absence of such debates which might raise concerns on a tradition's viability).

Thirdly, Cunningham (2009) is right in his observation that 'image' is a graded notion rather than an absolute concept that allows for strong binary oppositions. Still, one may wonder what kind of theological conclusions follow from this. It is striking that, whilst Cunningham rightly warns against deriving theological conclusions from empirical observations about race, sex et cetera, he goes on to draw theological conclusions from empirical observations about language and grammar, even English grammar for that matter, without noticing how precarious this is as a theological method. As Wittgenstein famously argued, the meaning of language is in its use. Therefore, rather than asking how the word 'image' functions in English (or even Hebrew) grammar, we should ask in what kind of contexts and meanings it is put to use in the biblical texts themselves. And then again, despite all instructive caveats and qualifications made by Cunningham, which we should definitely take into account, we cannot escape the conclusion that, according to the biblical texts, the image of God is somehow uniquely present in the human species (in fact, Cunningham is probably one of the first interpreters who doubts this). Of course, we might decide to disconnect our own theological views from the Bible here, arguing that we should extend the notion of the image of God to the non-human realm even though the Bible does not do so. However, unless there is some deeper motive in biblical theology which justifies this move (which I do not see), there is an obvious price tag connected to it. Given the paradigmatic and normative status of Scripture in Christian theology, it becomes difficult to present such a view as standing in continuity with the Christian tradition, or to recommend it to the contemporary Christian community as a viable option.

Therefore, we still find ourselves at the very place where we started: Christians typically ground their affirmation of human dignity on the doctrine of the imago Dei, which, in turn, requires a conception of the human species as being different from all other beings. And the question continues to be, therefore, how we can make sense of this affirmation in light of the profound ways in which it is challenged by evolutionary theory. This question becomes even more urgent when we acknowledge that the image of God, despite the fact that this phrase only rarely occurs in the Bible, is nevertheless a 'central, canonical idea' (Van Huyssteen 2006:149). Drawing upon the work of James Luther Mays, Van Huyssteen (2006:122) argues that although apart from Genesis the notion of the 'image of God' is hardly used for the human being in the biblical story, 'what it stands for theologically does in fact become the structural theme of the biblical account of God and humankind'. Indeed, the dramatic story in which the Bible seems most interested is the narrative of God's dealings with both the people Israel and the entire human race. Thus, it implicitly underlines the uniqueness of the human species from beginning to end also without explicitly mentioning it or linking it to the notion of the imago Dei. But in what does this uniqueness reside?

\section{Uniqueness as a theological category}

If we want to retain the notion that humankind somehow fundamentally belongs to another category than other species, evolutionary theory helpfully reminds us that we should avoid superficial appeals to empirical characteristics which seem to set us apart as unique beings. As 
David Clough (2009:156) points out in a recent contribution 'against human separatism', the 'most frequently offered markers of difference - rationality, intelligence, and language - are unable to identify a qualitative difference between humans and other creatures' (2009:152). Indeed, contemporary research has made clear that especially some of the great apes also possess these capabilities in various (at least rudimentary) ways. Still, however, there might be distinctively theological reasons for considering humanity as somehow fundamentally different from the rest of creation. It is this option that we will explore in the present section.

In doing so, we should again proceed with some caution, because there might also be theological arguments which are seriously flawed. One example of this is the attempt to ground human uniqueness in the doctrine of the incarnation. Clough (2009) points to Karl Barth in this connection, according to whom creation is the external basis of the covenant with humanity established by God through Jesus Christ. That seems to imply a highly anthropocentric approach. Indeed, in his later work on The humanity of God, Barth (1960:51) goes as far as stating straightforwardly that, in Christ, 'God is human.' Although Barth does not use this insight to work out a strong notion of human uniqueness amidst the other living beings, Clough (2009:154) is definitely right when he observes that it is 'hard to envisage a higher of more absolute distinction that could be established between human beings and the rest of creation'. He then goes on to refute the idea that, in the incarnation, God somehow privileges humanity. The way in which he does this, however, is problematic and even hazardous. Clough (2009:155) argues that the Church has already broadened its understanding of the incarnation by moving from the description that God became a Jew, to the Nicene view that God became a human being, and so it might just as well go one step further on this path by understanding the incarnation in terms of 'God becoming a creature'. However, instead of considering the Church's forgetfulness about Christ's Jewishness as a form of progress, as Clough seems to do, we might rather regret this loss of Christological concreteness, especially in light of what should probably be seen as the dreadful anti-Semitic consequences of this age-old forgetfulness which culminated in the Holocaust. Therefore, rather than making the event of the incarnation even more bleak and general, we should re-appropriate its icky concreteness: God did not become a creature in the most abstract and inoffensive sense of the word, but God became a first-century (i.e. pre-modern), male Palestinian Jew.

The reason why the incarnation cannot be construed as a theological ground for safeguarding humanity's unique dignity is that it does not refer to something which elevates us humans above the animals, but to something which rather degrades us below them, namely the fact that we alone of all living beings are guilty of sinning against God. For although there have always been dissenting voices (cf. Van Driel 2008), the majority view in the Christian tradition throughout the ages has been that the incarnation was made necessary by human sin. But even when one would opt for the 'incarnation anyway' view, the doctrine of sin should make us pause before we ascribe all kinds of unique metaphysical compliments to humanity. Although primatologists and (other) ethologists have started to ascribe some form of morality to certain non-human animals and, following this, some have even cautiously suggested the possibility of animal sin (cf. Deane-Drummond 2009:160-170), the Bible ascribes clearly the responsibility for sin to humans and humans alone. And clearly, 'humanity does have a distinctive capacity for "sins" that outweighs anything remotely recognisable in nonhuman animal behaviour' (Deane-Drummond 2009:168). As such, according to the biblical account, the most conspicuous aspect in which we human beings are unique is our capacity for committing evil and causing suffering in the world. Whereas this definitely marks us off from the rest of creation, it is not so clear that it helps us to carve out a robust notion of human dignity or human rights.

Perhaps because, arguably, human beings never entirely coincide with their state of being sinners, there is something more to be said about human uniqueness from a theological point of view (cf. Vorster 2001:8-12, 2008:197-199). A promising way forward here is to re-examine the doctrine of imago Dei along lines which have been suggested in both recent biblical scholarship and Christian theological anthropology. Classical accounts of this doctrine famously tried to define some unique natural characteristic which allegedly distinguished human beings from other creatures. For example, as opposed to (other) animals, only human beings were supposed to possess a soul, or rationality to mention only the two options which have been most prevalent in the theological tradition. Quite independently of their vulnerability to evolutionary claims, however, it has become clear that such 'substantive' theories of the image of God (finding the image in some substantial quality) cannot stand the test of exegetical scrutiny: quite simply, the identification of the imago Dei with either the soul or reason does not occur in the Bible; rather, its background is to be found in various forms of Greek philosophical thought. Both biblical scholars and systematic theologians have therefore come up with proposals to reinterpret the nature of God's image in humanity by studying its biblical ramifications. Indeed, the biblical concept of imago Dei has been the object of intense scholarly attention in recent years (for a masterful survey and evaluation of the history of its interpretation, see Van Huyssteen 2006:111-162; cf. the only slightly earlier accounts in Middleton 2005 and Shults 2003). Despite Cunningham's (2009) complaint about the large variety of interpretations, these recent examinations disclose a lot of overlap in that most of them point into one of two directions: the biblical notion of the image of God should be understood either in functional or in relational terms. Usually, biblical scholars, who focus primarily, or even exclusively, on the first chapters of Genesis, endorse a functional interpretation, whereas systematic theologians who take into account the entire canonical framework end up with a relational view (Cortez 2010:30).

Perhaps, however, the two of these are not as mutually exclusive as they are sometimes supposed to be. In any case, 
the seminal Genesis-text links the notion of the image of God both to a relationship ('male and female God created them') (Gn 1:27) and to a particular function or task, viz. to have dominion over the animals. Because the functional reference, which is spelled out twice (Gn 1:26, 28), is arguably the more prominent and certainly the most explicit one, let us start there. We might then suggest that what is theologically distinctive about God's human creatures is that they are being called to rule and have dominion over the earth. Understandably, from an ecological point of view, there continue to be worries about the harsh language which is used in these verses ('subdue', etc.). Following on from previous research, however, Richard Middleton (2005:89-90) has convincingly argued that both against the background of extra-biblical contemporaneous material in which the king figures as the image of God and in light of Genesis 1 as a whole, the dominium terrae should not be understood as including the use of violence (cf. Middleton 2005:263-269; Van Huyssteen 2006:157-158). Rather:

[T] he human task of exercising power over the earth is ... modeled on God's creative activity, which, in Genesis 1, is clearly developmental and formative, involving the process of transforming the toh $\hat{u}$ waboh $\hat{u}$ into an ordered, harmonious cosmos. (Middleton 2005:89)

So it is precisely in being called to be God's image that the human being is summoned to mirror the wisdom, generosity and creative love by means of which God made the earth into a habitable place. There is even a striking chiastic parallelism in God's first forming and then filling the earth, on the one hand, and humanity's vocation to fill and then organise the earth, on the other. However this may be, the Genesis account stands in strong contrast with the creation-by-combat myths from the Umwelt which, to be sure, we also find in other parts of the Old Testament. So here, then, we have a theological account of what makes humanity unique in creation, in terms of its royal and priestly God-given task to represent God on earth by being a blessing to its many inhabitants.

Whilst acknowledging that this might be the case, David Clough (2009:153) has nevertheless argued that this interpretation of the image of God should not be seen as grounds for 'human separatism', because 'the Bible repeatedly affirms that ... each living thing has a part in God's purposes'. Thus, he suggests that being in the image of God does not make humanity more unique amongst God's creatures than any other species. It is a kind of species specificity - the kind of distinctiveness which every species has by the very fact of being a species of its own - rather than a unique characteristic that sets humankind apart from the rest of creation. Whereas there certainly is a humbling element of truth in this argument - we should not underestimate the special relationships God has with the non-human parts of creation - it seems to me that, as a whole, it is unconvincing. Of course, one can always ask how specific a species must be to be 'really' unique; however, clearly, none of the other species has received such a huge and wide-ranging responsibility for the whole of creation, including the other animals, as humankind has.

It is from this unique responsibility, or so I would suggest, that our human dignity is derived. For when it is declared in Genesis 9 that the human life, in contrast to the lives of animals, is inviolable, this is justified by means of an appeal to the fact that the human being is made in the image of God. Therefore, from a Christian point of view, we should reject a comprehensive moral identification of humans and animals (cf. Schenderling 1999). It is important, however, not to exchange the order here: our responsibility precedes and grounds our dignity, rather than the other way around. In this way, our dignity can never legitimately become a cause for arrogance or boasting, nor for maintaining a purely anthropocentric view of the universe. Still, both our responsibility towards God, and the corresponding dignity that God has granted us, make us into unique beings on earth.

This point can be further corroborated when we take into account the relational interpretation of the image of God. In fact, this interpretation is closely linked with the functional one. For we are not only destined to be God's representatives on earth, consciously continuing and maintaining God's work of creation, but we are also the only beings who are addressed by God so that we should know this (Gn 1:28, cf. 26, where it is only said about us). As Robert Jenson (1983:320-321) has argued, from a theological point of view, humans are unique in that God speaks not only about them, but also to them, thus establishing a relationship with them. This relationship turns out to be reciprocal, in that human beings have, from their earliest times, responded to their being addressed by God by means of ritual and prayer. As Wentzel van Huyssteen (2006: passim) has helpfully reminded us, our relationship to God is never an abstract decontextualised thing, but always embedded in profoundly embodied patterns of behaviour. Our capacity to engage in personal reciprocal relationships also extends to our fellow human beings and this, as well, can be seen as an essential element of what it means that we are made in God's image ('male and female God created them'). Still, if anywhere, it is in our religious propensity that a distinctive and unique-making natural characteristic of the human species can be found. Paraphrasing Reinhold Niebuhr, Van Huyssteen (2006) writes that:

... humans are in fact driven to something beyond reason, a selftranscendence, and it is this existential longing for a God who transcends the world that really sets human beings apart from other creatures. (p. 133)

Or, to quote a stunningly similar insight of John Calvin: 'It is only the service of the Lord ... which raises the human being above the animals' (Institutes I.3.3).

So, do we after all encounter here a natural, empirical characteristic that defines our human uniqueness and marks us off from the rest of creation? To my mind, this question should be answered in a very careful way. For it is only from the theological perspective that we took that we can then discover such a distinctively human empirical characteristic. It may even be the case that, in fact, starting from this perspective, we just define the human being by pointing to its remarkable capacity for spirituality and religion, thereby simply denying hominids in which it is missing the status of being 'really' human (and I am not sure whether Van Huyssteen succeeds in avoiding this). In any case, we should be very careful, again, not to read into our theology some arbitrarily favoured empirical characteristic, and declaring that to be unique-making. 
But then, finally, we do not need to do so either, because it is enough to define human uniqueness from the theological perspective of what it means to be created in the image of God. As we have seen, we do not need some other, empirically based faculty or attribute to warrant human dignity. If we were only special in God's eyes and because of our God-given tasks and relationships, we would still be very special - special enough to have inviolable rights. Clearly, however, in order to be able to live in these relationships and to fulfil these tasks, we have been endowed with many empirical characteristics which, though not unique-in-kind, and in that sense reminding us of our close ties to the animal world, are still unique-in-degree. As, for example, John Polkinghorne (2006:95) argues, 'the consciousness of our animal cousins seems to be different from human self-consciousness.' Likewise, when it comes to symbolic and linguistic behaviour, some have compared the difference between animals and humans as the difference between a two-dimensional and a three-dimensional use of them. For example, only humans can produce symbols about what does not exist or is not there (cf. Deane-Drummond 2009:165). Similar arguments can be produced with respect to rationality (which only in human beings leads to science, technology, socio-political organisation and cooperation etc.), art, literature, music, economic behaviour, and other elements of 'cultural evolution'. And, if at all, we are willing to ascribe features such as personhood and morality to animal primates, it is clear that these function at a much more complex, much more developed and much richer level in human beings.

One might even argue that, in all these cases, the levels are so distinct, that the differences in degree ... amount to differences in kind' (Polkinghorne 2006:96; cf. Cortez 2010:143, n. 10). And even if we resist the temptation of, in this way, once again looking bottom-upwards for empirical unique-making behavioural features, we have ample reason to continue to distinguish between human beings on the one hand and animals on the other. However, we might just as well follow the current fashion of speaking about 'human and nonhuman animals', thus underlining our biological connectedness to the other primates - for we are special anyhow. The stories of Genesis and evolutionary theory neatly converge in that both of them point to humanity as the astonishing culmination of the entire process of creation. As one evolutionary scientist, the paleoanthropologist Ian Tattersall (1998:188), has phrased it: 'Homo sapiens is not simply an improved version of its ancestors - it's a new concept.' From the perspective of Christian theology, then, this uniqueness continues to undergird not only humanity's special responsibility with regard to creation, but also its dignity and inalienable rights.

\section{Conclusion}

After having reviewed briefly the roots of the classical JudeoChristian view on human uniqueness and human dignity in the first chapters of Genesis, I explored what might be called the 'evolutionary argument' against this view, examining whether, in response to this argument, Christian theology should widen the concept of imago Dei so as to include other beings as well as humans, thus relinquishing the idea of human uniqueness. I concluded, however, that this move is deeply problematic and so turned to a discussion of some recent attempts to define both human uniqueness and the image of God in theological rather than empirical terms. One of these attempts was found wanting, but another one, focusing on human relationality and responsibility, enables us to reconcile the idea of human uniqueness as encapsulated in the biblical notion of the imago Dei with contemporary evolutionary theory.

\section{Acknowledgements Competing interests}

The author declares that he has no financial or personal relationships which may have inappropriately influenced him in writing this article.

\section{References}

Barth, K., 1960, The humanity of God, John Knox Press, Richmond.

Clough, D., 2009, 'All God's creatures: Reading Genesis on human and non-human animals', in S.C. Barton \& D. Wilkinson (eds.), Reading Genesis after Darwin, pp. 145-161, Oxford University Press, Oxford. http://dx.doi.org/10.1093/acprof:o so/9780195383355.003.0009

Conradie, E.M., 2005, An ecological Christian anthropology: At home on earth?, Ashgate, Aldershot.

Cortez, M., 2010, Theological anthropology: A guide for the perplexed, T\&T Clark, London.

Cunningham, D.S., 2009, 'The way of all flesh', in C. Deane-Drummond \& D. Clough (eds.), Creaturely theology: On God, humans and other animals, pp. 100-117, SCM Press, London.

Deane-Drummond, C., 2009, Christ and evolution, Wonder and wisdom, SCM Press, London.

Hull, D., 1989, The metaphysics of evolution, State University of New York Press, Albany. Jenson, R., 1983, 'The praying animal', Zygon, Journal of Science and Religion 18(3), 311-325.

Middleton, J.R., 2005, The liberating image: The imago Dei in Genesis 1, Brazos Press, Grand Rapids.

Moreland, J.P., 2009, The recalcitrant imago Dei: Human persons and the failure of naturalism, SCM Press, London.

Polkinghorne, J., 2006, 'Anthropology in an evolutionary context', in R. Kendell Soulen \& L. Woodhead (eds.), God and human dignity, np., William B. Eerdmans, Grand Rapids.

Rachels, J., 1990, Created from animals, Oxford University Press, Oxford.

Schenderling, J., 1999, Mens en dier in theologisch perspectief: Een bijdrage aan het debat over de morele status van het dier, Boekencentrum, Zoetermeer.

Shults, F.L., 2003, Reforming theological anthropology: After the philosophical turn to relationality, William B. Eerdmans, Grand Rapids.

Tattersall, I., 1998, Becoming human: Evolution and human uniqueness, Harcourt Brace, NY.

Van Driel, E.C.H.R., 2008, Incarnation anyway: Arguments for Supralapsarian Christology, Oxford University Press, Oxford.

Vanhoozer, K., 1997, 'Human being, individual and social', in C. Gunton (ed.), The Cambridge companion to Christian doctrine, pp. 158-188, Cambridge University Press, Cambridge. http://dx.doi.org/10.1017/CCOL0521471184.011

Van Huyssteen, J.W., 2006, Alone in the world? Human uniqueness in science and theology, William B. Eerdmans, Grand Rapids.

Vorster, J.M., 1999, 'Calvin and human rights', Ecumenical Review 51(2), 209-220. http://dx.doi.org/10.1111/j.1758-6623.1999.tb00030.x

Vorster, J.M., 2000, 'The emergence of an ethos of human rights', Studia Historia Ecclesiasticae 26(2), 116-141.

Vorster, J.M., 2001, "n Christelike teorie van menseregte' [A Christian theory of human rights], In die Skriflig 35(1), 1-23.

Vorster, J.M., 2006, 'Christian attitude and the human dignity of women', Studia Historiae Ecclesiasticae 32(2), 229-268.

Vorster, J.M., 2008, “n Christelike perpektief op menswaardigheid' [A Christian-ethical perspective on human dignity], Nederduits Gereformeerde Teologiese Tydskrif 49(1/2), 195-205.

Vorster, N., 2011, 'The Augustinian type of theodicy: Is it outdated?', Journal of Reformed Theology 5(1), 26-48. http://dx.doi.org/10.1163/156973111X562201 